\title{
A HATÁRTÉRSÉG TÉRSZERKEZETI JELLEMZŐI
}

\author{
(Features of the Border Region's Spatial Structure)
}

\section{HARDI TAMÁS}

Kulcsszavak:

hatärtérség térszerkezet városhálózat területifejlettség

A tanulmány a szlovák-magyar határtérség területi szerkezetét elemzi. A határtérség területi kiterjedését nagymértékben befolyásolja a térszerkezet, a városhálózat, a közlekedési tengelyek. A szlovák-magyar államhatár hosszú, változatos társadalmi-gazdasági és természeti környezetet választ szét. Ezek a területek valaha egy állami keretbe tartoztak, igy esetükben érdekes annak tanulmányozása, hogy milyen területi következményekkel jár egy államhatár a területi fejlettségre, városhálózatra, a lakosság mozgási pályáira. A tanulmány végén empirikus kutatásunk eredményeként bemutatjuk a kérdöivünk válaszadóinak fö célterületeit a másik állam határtérségében.

\section{Bevezetö}

A szlovák-magyar határ $679^{1}$ kilométeres hossza változatos természeti-társadalmi környezetet vág ketté. Nem beszélhetünk általában szlovák-magyar határtérségről, hiszen alfơldektől hegyvidékig, nagyvárosi agglomerációktól városhiảnyos perifériákig több, eltérö jellegzetességekkel bíró területet fedezhetünk fel vizsgálataink során. Megfigyelhetjük azt a törvényszerüséget, hogy a határ mindkét oldalán a gazdasági-társadalmi fejlettségben egy nyugat-kelet irányú lejtő létezik.

A határtérség fejlettségbeli különbségeire rányomja a bélyegét az a tény, hogy valaha egy államalakulathoz tartozott. Az 1920. évi trianoni békeszerzödésben a határt elsősorban gazdasági, katonai-stratégiai és közlekedés-földrajzi szempontok figyelembevételével jelölték ki (Hevesi-Kocsis 2003). Így a mindennapi élet szervezése szempontjából oly fontos lakossági kapcsolatok hálózata, a településhálózat szempontjai, illetve az etnikai szempontok háttérbe szorultak.

A határtérség Közép-Európa egyik legdinamikusabban fejlödő területétól, Bécs vonzáskörzetétől a nagyrégió peremvidékéig húzódik. A szlovák-osztrák-magyar hármashatár vidék, kiegészítve a dél-cseh területekkel egész Európa egyik legdinamikusabb térsége. Itt elsősorban Bécs, de ma már Pozsony központi funkciói is épitik határon átnyúló vonzáskörzeteiket, egybekapcsolva olyan térségeket, amelyeket alig két évtizede még világrendszerek határa választott el egymástól, de korábban egy államalakulathoz, az Osztrák-Magyar Monarchiához tartoztak. Az egykori birodalom e centrumtérségének fejlỏdési potenciáljára már a kilencvenes években felhivta a figyelmet Gorzelak, amikor a „közép-európai banán” részeként határozta meg azt (Gorzelak 1995; Rechnitzer 1998). Ez a Gdansktól Prágán át Budapestig húzódó nagytérségi fejlődési tengely magába olvasztja határtérségünk nyugati sza- 
kaszát, míg keleti felén ez a dinamika nem vagy csak lokálisan, mérsékelten érezhető. Mindemellett még számos térségi specialitás is található a vizsgálati területen, amelyeket tanulmányunkban kívánunk bemutatni.

\section{Határtérség és térszerkezet}

Tanulmányunkban a szlovák-magyar határtérséget vizsgáljuk, annak térszerkezeti meghatározottságait. Határtérség alatt azt a határ menti területet értjük, amelynek életére, gazdasági-társadalmi folyamataira jelentôs befolyást gyakorol az államhatár léte. Hansen (1983) definíciója még egy olyan korban született, amikor az európai határok többé-kevésbé elválasztó jellegủek voltak. Napjainkban mindenképpen ki kell emelnünk azt a tényt, hogy a határtérség kiterjedését már nem (csak) maga az államhatár, hanem az elválasztott határ menti területek térszerkezeti jellegzetességei, a város- és közlekedési hálózatok határon átnyúló kapcsolódásai, valamint a határ két oldalának eltérő gazdasági-társadalmi jellemzői szabályozzák. Ezek alakítják ki azokat a határon átnyúló lakossági és gazdasági mozgásokat, amelyek a nemzetállami tér határ menti területeit olyan különlegessé teszik. Napjainkban és térségünkben tehát azt tekinthetjük határ menti térségnek, amelynek mindennapi életét alapvetöen befolyásolják a szomszédos határtérséggel fenntartott interakciók. A térbeli határokkal foglalkozó irodalom egyre többször utal a gyakorlati élet azon tényére, hogy a régiók (itt a különböző államokhoz tartozó térségek) közötti éles elhatárolás ma már a múltté, $s$ egyre inkább a rendszerek közötti átmeneti jelleggel bíró övezetek kialakulását figyelhetjük meg (Fleischer 2001; Novotny 2007). Valójában a két definíció együtt érvényes, hiszen továbbra sem negligálhatjuk a határ térszerkezet formáló szerepét, még akkor sem, ha a schengeni belső határok esetében az államhatár fizikai korlátozó szerepe megszünt. Még az államhatár teljes megszünése esetén is (mint pl. a belsó német határ) a vonal történelmi szerepénél fogva megmarad, hiszen a határ menti területek fejlettségi, hálózati jellegzetességeinek kialakításakor fontos szerepe volt a nemzetállami fejlödés során. Az EU belső határai is csak az átlépés teljes szabadságát biztosítjảk, de a mindennapi életet szabályozó nemzetállami rendszerek különbségei megmaradtak. Az EU külsỏ határai, s a nem-EU határok pedig továbbra is fizikai értelemben akadályozzák az interakciók szabad alakulását. E definíció-páros tehát a határtérség funkcionális megközelítését tartalmazza, s így kevésbé ad módot a közigazgatási természetủ lehatárolásokra. Látható, hogy egyik meghatározás alapján sem vagyunk képesek egy éles, pontos határtérség lehatárolást tenni, hiszen ahány funkció, annyi mozgástér létezik, mást fog kialakítani a munkavállalás, mást a bevásárlás stb. Ugyanakkor sok esetben kénytelenek vagyunk kompromisszumot kötni, s pl. a jelen kutatás vonatkoztatási területét kijelölni. Korábbi vizsgálatok eredményeire támaszkodva a kutatásunk vizsgálati területének lehatárolásakor egy $20 \mathrm{~km}$ széles sávot minösítettünk automatikusan határtérségnek, majd ezt tapasztalati úton kiegészítettük olyan, fökẻnt városi, 
Tér és Társadalom, 22. 2008. 3. 3-25. p.

urbánus területekkel, amelyek a határon átnyúló mozgások központjai, a határon átvezetỏ utak elsö fontos állomásai.

Meghatározásához az alábbi jelenségek vizsgálatát végezhetjük el:

- Vizsgálnunk kell a határtérség elhelyzekedését a határos államok területi fejlettségi struktúrájában, valamint fontos információt rejt a határtérségek közötti fejlettségi különbségek bemutatása is. A strukturális alapok, a centrum periféria viszonyok bemutatása mellett fontos azoknak a térszerkezeti fejlódési tengelyeknek az ismerete, amelyek a nemzetállaminál nagyobb területi egységek, nagyrégiók keretei között alakulnak, alakultak ki. Ezeket meghatározhatják a városhálózat, a történelmi állami, birodalmi keretek, de a modern gazdaság európai léptékü területi jellemzői is.

- A lakossági mozgások (vagy lehetséges mozgások) egyik legfontosabb befolyásoló tényezője a városok vonzásterei, a városhálózat és az államhatár viszonya. A határ elválasztó szerepe korlátozza a központok elméleti vonzáskörzeteit s viszont, kialakulnak olyan térségek, amelyek a hazai városhálózat vonzásteréből kimaradnak vagy gyengén integráltak, városhiányos perifériák. Általában azt mondhatjuk, hogy az államhatár történelmi térformáló szerepének egyik legfontosabb manifesztációja a városi vonzásterületek átalakítása. Napi mozgásaink nagy része a településhálózati jellegzetességekhez igazodik: a munkahely, a szolgáltatások igénybevétele, az iskola egyre kevésbé kötődik a lakóhelyhez, azokat különböző településeken, központokban vesszük igénybe. A határ mentén élők számára ezek lehetnek hazaiak, de lehetnek a gyakran térben közelebbi, de másik állam területére esỏ települések.

- Általában az €lőző kettővel egymást erősítő kölcsönhatásban van a közlekedési hálózat alakulása is. A nagy hálózati elemek határokat keresztező irányai általában a tranzitforgalom szolgálatában állnak, amelyek a hatrátérség szempontjából önmagukban nagy jelentőséggel nem bírnak. Maga a határ átlépése ma már nem jár időveszteséggel, így a határ korábbi, forgalmat megállító hatása sem jelentkezik. Ezek a pályák ugyanakkor nagy jelentőséggel bírhatnak a határtérségek megközelíthetősége szempontjából, ami egyéb más tényezők jelenléte esetén a szerzett periférikus helyzet oldását eredményezheti. A közlekedési hálózat másik fontos szintjét a határtérség belsó feltárását elősegítő hálózati elemek alkotják, amelyek határon átnyúló integrációja gyakran nehezebben valósul meg, mint a nagy tengelyeké. A határtérségen belüli térszerkezet egyik legfontosabb alakítói ezek az utak (de ide tartoznak még a hidak, kompok, tömegközlekedési vonalak), hiszen a központok (a határ másik oldalán elhelyezkedỏ központok) megközelíthetőségét befolyásolják.

- Mindezek alapján rajzolódnak ki azok a mozgások, interakciók, amelyek a határtérségek belsỏ hálózatát, integrációját kialakítjảk. Ezek száma, intenzitása, iránya adja meg számunkra a határtérségi integráció alapvető típusait, amelyek alapján meghatározhatjuk az egész határtérség alapvető belső struktúráját. Ezeket a típusokat kiválóan bemutatja Martinez modellje (Martinez 1994, 7), melyre munkánk során támaszkodhatunk (1. ábra). 


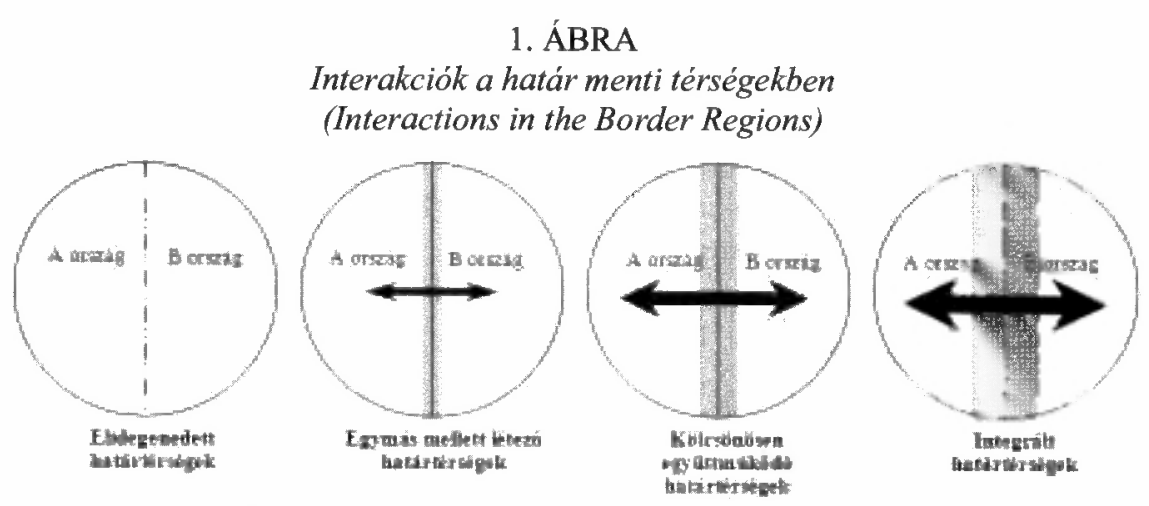

Forrás: Martinez (1994, 7).

- Az elidegenedett határtérségek között feszültségek jellemzők, a határ zártnak minösíthetó, és az interakciók a két terület között teljesen vagy közel teljesen hiányoznak, s mindkét állam idegenként, ellenfélként ismeri el a másik felet. Magyarországon ilyen szituáció csak nagyon rövid ideig és részlegesen állt fenn, a két világháború között a Kisantant államokkal szemben, valamint az ötvenes években a magyar-osztrák és a magyar-jugoszláv határ viszonylatában. A lakosság ekkor sem ismerte el idegenként a másik oldalt, ez a magyar határok sajátságos történetébỏl adódik.

- Az egymás mellett létezö országok között a helyzet pillanatnyilag stabil, a határ némileg nyitott, $\mathrm{s}$ lehetővé teszi a kétoldalú nemzeti kapcsolatok fejlődését. A két ország lakosai amolyan eseti ismertség szintjén érintkeznek egymással, de a határos országok csak zárt együttmüködéseket fejlesztenek egymással. Erre példa az osztrák-magyar határ a szocializmus időszakában.

- A kölcsönösen együttmüködő határtérségek esetében a két ország közötti stabilitás a jellemző. A gazdasági és társadalmi komplementer körülmények elősegítik az interakciók fejlődését, a határtérség területi bövülését. A határos országok baráti és kooperatív kapcsolatok kialakítására törekednek. A kilencvenes években a magyar határok mentén a háborús országok kivételével jellemzỏ volt a kapcsolatok ilyen szintje.

- Az integrált határtérségek (a határrégió) akkor jöhet létre, ha a stabilitás erős és permanens. A két ország gazdasága funkcionálisan összeolvad, s az emberek és javak áramlása a határon keresztül már nem korlátozott. A két ország egyetlen társadalmi rendszerként fogható fel. A kapcsolatok ilyen magas szintje még nem alakult ki Magyarország és a szomszédos országok viszonylatában.

A határtérségek térszerkezetére vonatkozó ismereteinket tehát két kontextusban is összefoglalhatjuk. Egyrészt vizsgálhatjuk az adott államok területi struktúrája szempontjából, így annak részeként elemezhetjük jellemzőiket, az adott államok centrumtérségeihez, fejlődési tengelyeihez, a nemzeti, nagytérségi városhálózathoz való viszonyát, amelyek együttesen végeredményben kialakítják a határtérséget, valamint elemezhetjük a határtérség belső strukturális jellemzőit, egységként kezelve a határ eltérő oldalain található területeket, s ezen belül írhatjuk körül az összetartozó elemeket. 


\section{A határtérségek fejlettségi különbségei a Kárpát-medencében}

A határ menti területek fejlettségbeli különbségeit NUTS3 szinten vizsgáltuk a Kárpát-medencében ${ }^{2}$. Ehhez a legegyszerübb, $\mathrm{s}$ többé-kevésbé egységesen beszerezhető valutaárfolyamon mért, egy före jutó bruttó hazai termék (GDP) összevetését végeztük $\mathrm{el}^{3}$. Megvizsgáltuk mértékét, a szomszédos határtérségek közötti különbségét, valamint változását 2001 és 2004 között (2. ábra). Bár adataink statisztikai értelemben összevethetők, még fenntartásokkal kell kezelnünk őket, így nem nélkülözhetik a magyarázatokat sem. A vizsgált területi egységek ugyanis eltérö nagyságúak, eltéró a határhoz viszonyított helyzetük, alakjuk. Horvátországban, pl. a vizsgált megyék lényegesen kisebb méretúek, mint a szomszédos magyar megyék, ráadásul a határ mentén elnyúlva perifériákat ölelnek fel. Nagyszombat kerület elnyúló alakja okán tartalmazza a magyar határtól távoli Nagyszombat adatait is, ami lényegesen megemeli a kerület kibocsátását. Reálisabb képet adnának a kistérségi/községi szintü értékelések, de összehasonlitható adatokat ezekre a szintekre beszerezni nem lehet. Így maradtunk a legkisebb területi egységeknél, amelyekre még GDP adat beszerezhető, a NUTS3 területeknél.

\section{2. ÁBRA}

A határ menti NUTS3 területi egységek fejlettségi szintje, változása a Kárpátmedencében a 2001 és 2004 GDP/fö adatok alapján

(Level and Change of Development of NUTS3 Border Regions in the Carpathian Basin by the Regional per Capita GDP in 2001 and 2004)

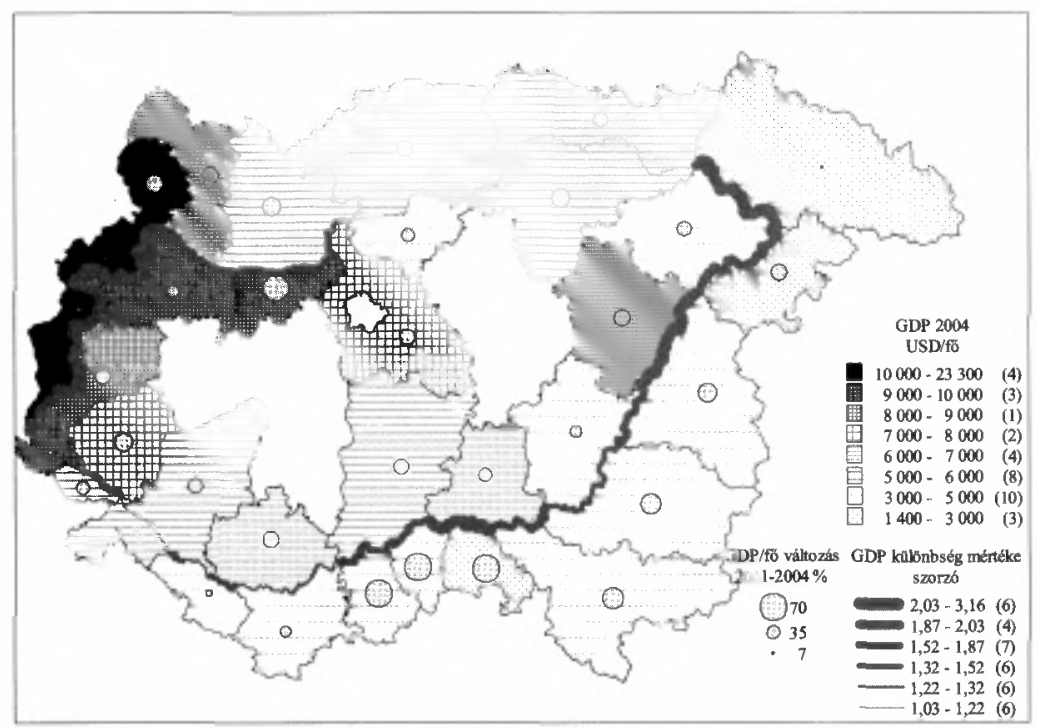

Forrás: Eurostat és nemzeti statisztikai hivatalok (UA, SRB, CRO) adatai alapján saját számítás és szerkesztés. 
A Kảrpát-medence határtérségeiben, bỏvebben az egész medencében a fejlettségi lejtök hasonló irányokat mutatnak. Az északnyugati, nagyvárosok (Bécs, Pozsony, Budapest) által határolt, de Bécs központú terület dominanciája feltünő, onnan kiindulva tapasztalhatjuk a kelet és dél felé mutató lejtőket. A fejlettségi lejtő aljára északkeleten, Kárpátalján és délkeleten, a vajdasági Észak-Bánátban bukkanunk. A vizsgált területen belül a legszegényebb (Kárpátalja) és a leggazdagabb (ÉszakBurgenland) terület között több mint tizenötszörös a mért különbség. Az egymással érintkezö, határos térségek esetében a GDP-vel mért fejlettségi szintek között nagy (akár háromszoros) különbségeket is találunk, míg máshol egymáshoz hasonló szintü területek találkoznak. A határ mindkét oldalán hasonló szintü fejlettséggel inkább a szegényebb területek esetében találkozhatunk. Így megállapíthatjuk, hogy a fejlettségi szintet nem minden esetben szakítja meg az államhatár jelenléte.

$\mathrm{Az}$ említett, Bécs központú fejlödési pólustól távolodva csökken a fejlettségi szint. Bár az osztásközök választása miatt ábránk ezt nem mutatja, de Pozsonytól Szlovéniáig érvényesül egy észak-dél lejtő a határ valamennyi oldalán. A legmagasabb GDP-vel Észak-Burgenland rendelkezik, majd az értékek fokozatosan mindig alacsonyabbak Közép-, illetve Dél-Burgenland, majd a Pomurje régió esetében. Hasonló csökkenés mutatható ki a magyar oldalon is.

Amennyiben megyei szint alatt, a kistérségek fejlettségét vizsgáljuk Magyarország esetében, akkor látható, hogy a megyéken belüli térszerkezet és a határok viszonya eltérő a fejlett és a kevésbé fejlett megyékben. Az északnyugati országrészben, Györ-Moson-Sopron, Vas és Komárom-Esztergom megyékben a határ menti kistérségek dinamikusan fejlödő besorolást kaptak. Az első két megyében ez mondhatni természetes, hiszen a két megyeszékhely és egy megyei jogú város (Sopron) a határ szomszédságában helyezkedik el. De további határ menti kistérségek is „fejlett” kategóriába kerültek. Komárom-Esztergom megye esetében annál feltủnőbb, hogy a megyeszékhely kistérsége mellett a Duna menti, tehát államhatár menti kistérségek közül valamennyi ezt a legmagasabb szintủ besorolást érte el. A többi határszakasz esetében azonban a kistérségek közepes vagy annál rosszabb értékeket mutatnak. Különösen rossz a helyzet a keleti megyékben (Borsod-Abaúj-Zemplén, SzabolcsSzatmár-Bereg, Hajdú-Bihar és Békés), ahol a határ menti kistérségek leszakadó helyzetben vannak, s megyén belül is sokszor a leggyengébb eredményeket érik el.

A rendszerváltás után felértékelödtek a nyugati határtérségek és városok. Így kialakult egy érdekes lépcsőzetesség kelet és délkelet irányába: periférikus határ menti területek érintkeznek náluknál jóval szegényebb, de a saját országukban fejlettnek számító, s dinamikusan növekedő területekkel. Érdekes jelenség, hogy a legnagyobb fejlettségbeli különbségek ezekben a térségekben alakultak ki. Tehát a viszonylagos fejlettség a határ nyugati, míg a dinamika a határ keleti (szegényebb) oldalán érvényesül. Burgenland és Nyugat-Magyarország határán, valamint a román-magyar és a szerb-magyar határon szinte tükörszerüen ismétlödnek ezek a különbségek.

Románia esetében Temes megye a fỏvárosi régió (Bukarest és Ilfov megye) után a harmadik legmagasabb egy fớre jutó GDP-vel rendelkezik. De Arad és Bihor megyék is a legjobbak között vannak, meghaladva a román átlagértékeket. Mindegyik megye 
esetében elmondható, hogy Románia legdinamikusabb megyéi közé sorolhatók, ha a 2001 és 2004 közötti növekedésüket vesszük alapul. Lényegében ezek a területek Románián belül hagyományosan fejlettnek számítottak történelmi okoknál fogva is.

A Vajdaságban is hasonló a helyzet. Mindig is Szerbia legfejlettebb térsége volt, GDP-je ma is meghaladja a szerb átlagot. Ugyanakkor Csongrád megyén belül Szegeddel, mint fejlődő kistérséggel, Csongrád többi részén, valamint Bács-Kiskun megyén belül viszont átlagos vagy átlag alatti fejlettségü területekkel találkozik.

Így ismereteink alapján egy érdekes mátrixot állíthatunk fel, amelyben egyszerre értékeljük a saját országon belüli és a szomszédos kistérséghez viszonyított fejlettségi szintet (1. táblázat).

Megállapithatjuk, hogy határtérségeink általános fejlettségi szintjét az adott állam fejlettsége határozza meg, míg dinamikáját az államhatárokhoz, a fó kárpátmedencei áramlási irányokhoz való viszonya. Itt megkülönböztethetünk „dinamikus”, valamint „szélárnyékban” levo határtérségeket.

Dinamikusnak nevezhetjük a nyugat-keleti érintkezési felületeket, valamint déli határunk keleti felét. Ezeken a szakaszokon erősödnek a határon átnyúló interakciók, városhálózati, vonzáskörzeti kapcsolatok. Jelentös a határok átmenő forgalma is. Szélárnyékban vannak azonban északi határunk keleti részei, valamint déli határunk nyugati fele. Ezeken a szakaszokon kisebb fejlettségbeli eltéréseket találunk (az egy lakosra jutó GDP értékek között nines másfélszeresnél nagyobb különbség).

\section{TÁBLÁZAT}

$A$ határ menti területek fejlettségi mátrixa

(Development Matrix of the Border Regions)

\begin{tabular}{|c|c|c|c|}
\hline \multirow{4}{*}{ 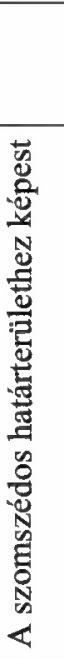 } & & \multicolumn{2}{|c|}{ A saját országában } \\
\hline & & $\begin{array}{c}\begin{array}{c}\text { Fejlettebb terïletek közé } \\
\text { sorolt }\end{array}\end{array}$ & $\begin{array}{c}\begin{array}{c}\text { Fejletlenebb területek közé } \\
\text { sorolt }\end{array}\end{array}$ \\
\hline & fejlettebb & $\begin{array}{l}\text { Pozsony fóváros, Kassa } \\
\text { (Sk), Győri, Komáromi, } \\
\text { Tatai, Esztergomi kistér- } \\
\text { ség, Nagykanizsa, Pécs, } \\
\text { Szeged, Debrecen }(\mathrm{Hu})\end{array}$ & $\begin{array}{l}\text { Burgenland (A), Muravidék } \\
\text { (Slo), Szlovákiával, Ukrajnával, } \\
\text { Romániával, Jugoszláviával, } \\
\text { Horvátországgal határos, máshol } \\
\text { nem említett kistérségek (Hu) }\end{array}$ \\
\hline & $\begin{array}{l}\text { fejletle- } \\
\text { nebb }\end{array}$ & $\begin{array}{l}\text { Dunaszerdahelyi járás, } \\
\text { Komáromi járás (Sk), } \\
\text { Nagyvárad, Arad, Te- } \\
\text { mesvár (Ro), Vajdaság } \\
\text { (Yu), Soproni, Köszegi, } \\
\text { Szombathelyi, Körmendi, } \\
\text { Lenti kistérség }(\mathrm{Hu})\end{array}$ & $\begin{array}{l}\text { Érsekújvári és a kelet-szlovákiai } \\
\text { járások Kassa kivételével (Sk), } \\
\text { Baranya háromszög és a Dráva } \\
\text { menti területek (CRO), } \\
\text { Őriszentpéteri, Kapuvári, Csor- } \\
\text { nai, Encsi, Szikszói kistérség } \\
\text { (Hu) }\end{array}$ \\
\hline
\end{tabular}

Forrás: Saját szerkesztés. 
A munkanélküliségi mutatók vizsgálatánál természetesen figyelembe kell venni azok országonként eltérő számítási módjait. Ennek ellenére az összehasonlításra azért alkalmas munkanélküliségi ráták is érdekes térszerkezetet mutatnak a Kárpátmedence határtérségeiben (3. ábra). Az általános fejlettséghez hasonlóan itt is érvényesül a nyugat-keleti lejtő, $s$ az északnyugat-délkeleti lépcsőzetesség. A keleti NUTS3 egységek munkanélküliségi mutatói mindenhol magasabbak az országos átlagoknál. Ugyanakkor az általános fejlettségbeli lejtővel szemben, a határok nyugati oldalán gyakran magasabb a munkanélküliség, mint a határok keleti oldalán. Ez a mintázat megismétlődik Észak-, illetve Közép-Burgenland és Györ-MosonSopron megye, valamint délkeleti megyéink és Nyugat-Románia találkozásánál. Jellemzö, hogy az összehasonlíthatóság kedvéért alkalmazott 2005. év óta ezek a különbségek növekedtek. Nyilván ez összefügg azzal a gazdasági dinamizmussal, amit korábban már leírtunk, $\mathrm{s}$ az országok nyugati határvidékére jellemző. Ez a megállapítás tehát a már bemutatott északnyugat-délkeleti irányú fö térszerkezeti vonalra érvényes.

\section{3. ÁBRA}

A határ menti NUTS3 területi egységek munkanélküliségi rátája a Kárpátmedencében

(Unemployment-rate of NUTS3 Level Border Regions in Carpathian Basin)

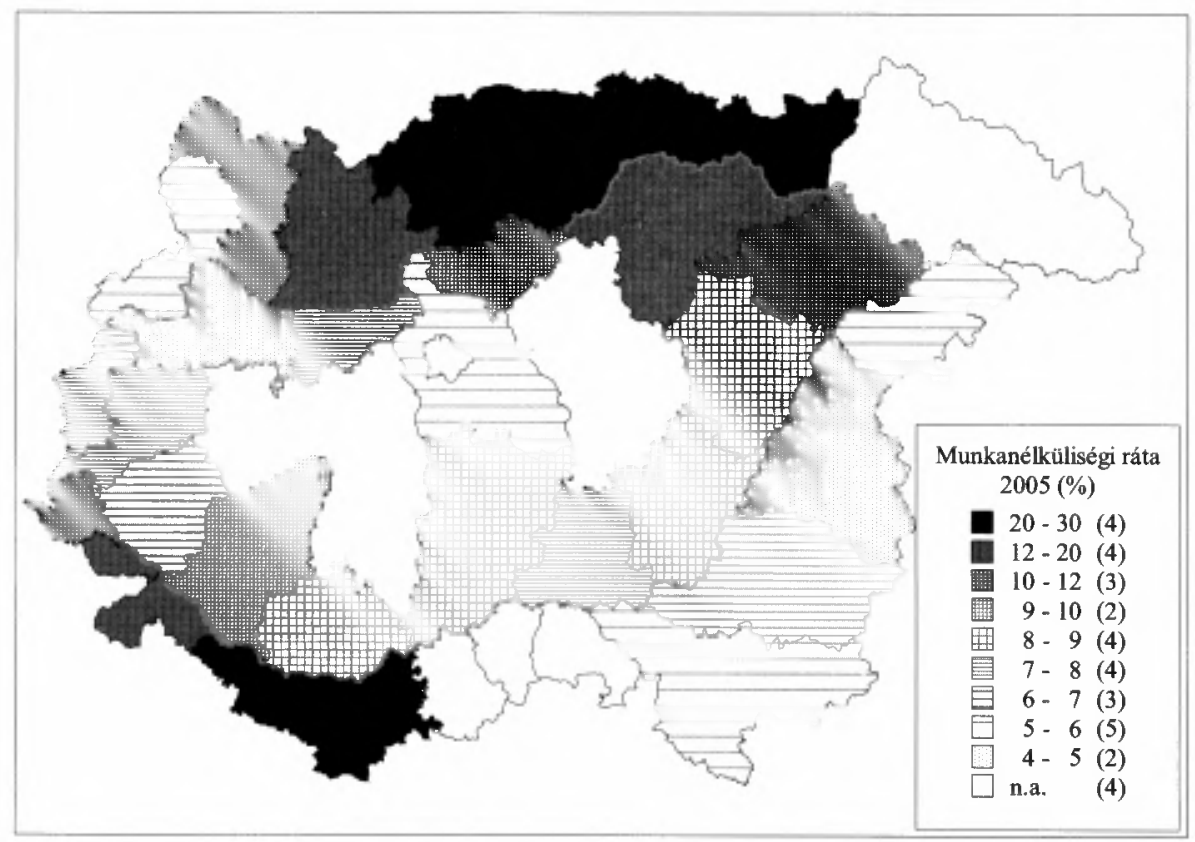

Forrás: Eurostat és nemzeti statisztikai hivatalok (CRO) adatai alapján saját számítás és szerkesztés. 
Ezeken a „lépcsős” területeken kívül határaink mentén rendre a hazainál nagyobb munkanélküliségü térségek helyezkednek el. (Bár nincs hivatalos adatunk, de Kárpátalja és a Vajdaság esetében is ez a helyzet.) Különösen kirivó a különbség a dunai szlovák-magyar határszakaszon, ahol a hazaihoz mérve jelentős (bár gyorsan csökkenő) munkanélküliséget találunk a másik oldalon. Míg északi határainknál egyaránt súlyos helyzetben lévö területeket találunk mindenhol. Nem véletlen, hogy jelentős számú munkaerő ingázás a dunai határszakaszon alakult ki, ahol az álláshelyek számának eltérései diktálják a mozgást Szlovákiából Magyarország felé, s hasonló szituációba kerültek délkeleti határtérségeink, ahol Magyarországról Románia felé indult jelentős ingázó forgalom. Ezzel szemben osztrák-magyar viszonylatban a határon átnyúló munkavállalás okaiként elsősorban a jövedelmi különbségeket és strukturális problémákat (hiányszakmák) nevezhetünk meg.

\section{A szlovák-magyar határtérség a Kárpát-medencében}

Jelen fejezetben tovább kívánjuk finomítani a határtérség fejlettségi különbségeiről alkotott képünket. Elöször a 2005. évi NUTS3 területi egységekre mért GDP alapján vetjük össze az egyes területek fejlettségét, majd a kistérségek/járások fejlettségi különbségeit vizsgáljuk meg.

A NUTS3 szinten elöállított GDP ${ }^{4}$ alapján jól látható, hogy mindkét állam legfejlettebb területei a közös határ mentén találhatók. Egyértelmủen kimutatható a nyugati szakasz erős gazdasági koncentrációja. A két főváros mindkét államban jelentős, s növekvő mértékben koncentrálja az eloállított terméket. Pozsony 1995-ben az országban elóállított GDP 24,6\%-ával, addig 2005-ben már 27,3\%-ával rendelkezett, Budapest koncentrációja ennél nagyobb mértékủ, hiszen 1995-ben 33,9\%, míg 2005-ben 35,9\% volt. A határ menti NUTS3 egységek közül a nyugatiak növekedése dinamikus. Mind Magyarországon, mind Szlovákiában 1995 és 2005 között az országos átlagot meghaladó növekedés ezekben a megyékben volt tapasztalható. Szlovákiában Pozsony után Nagyszombat (Trnava) kerület adja a legmagasabb egy före jutó GDP-t, de évtizedes távlatban Nyitra (Nitra) és Zsolna (Zilinsky) kerület mutatja a Pozsony utáni leggyorsabb növekedést. Az országban előállított termékből való részesedésük is növekedett az évtized alatt, miközben Besztercebánya, Eperjes és Trencsény kerületének részesedése csökkent. Keleten csak a Kassai kerület növekedése számottevő, az országos átlaghoz közeli. Mindezek alapján látható, hogy az ország gazdasági ereje a nyugati és északi területekre öszpontosul, míg keleten Kassa szigetként emelkedik ki. Vizsgálatunk szempontjából fontos tény, hogy a jelentős gazdasági erőt képviselö és átlag felett növekedő kerületek (Zsolnai kerület kivételével) a magyar határ mentén - annak is a nyugati szakaszán - helyezkednek el. A szlovák gazdaság változásait érdekes lett volna 2005 után is nyomon követni, azonban összehasonlítható adatok csak erre a legkésőbbi időpontra álltak rendelkezésre. Vélhetö, hogy az azóta lezajlott folyamatok (beruházások, új üzemek átadása) is a bemutatott térszerkezetre erősítenek rá. 
A határ magyarországi oldalán is a nyugati oldal mutatja a legnagyobb növekedést, s a fơváros utáni legmagasabb előallított terméket. Budapest (és Pest megye) súlya nagyobb, mint Szlovákiában Pozsony és Nagyszombat kerület súlya, akár a GDP-t, akár a lakosságszámot tekinjük. Így alapvetően fejlett nyugati megyéink ellenére is Magyarország egész területén, illetve a határ menti megyéket figyelembe véve is nagyobbak a regionális különbségek, mint Szlovákia hasonló vizsgálatánál. Magyarországon a nyugati megyék (Győr-Moson-Sopron és Komárom-Esztergom megyék) a vizsgált évtizedben messze az országos átlagot meghaladó módon növekedtek, s Budapest után az ország legfejlettebb megyéi lettek.

Jól látható a szimmetria: a nyugati szakaszon, a határ mindkét oldalán az adott országok legfejlettebb területei helyezkednek el. Szlovákiában a határos három nyugati kerület (Pozsony, Nagyszombat és Nyitra), míg Magyarországon a Budapest és a három megye (Pest, Komárom-Esztergom és Győr-Moson-Sopron) az adott állam GDPjének felét állítja elö. Különösen Szlovákiában ez az arány növekedni látszik. Ezzel szemben a keleti rész fejlettsége mindkét oldalon átlag alatti, igaz Szlovákiában szigetként kiemelkedik Kassa, de Magyarországon Miskolc ugyanezt nem tudja produkálni.

A határtérség vizsgálatát azonban szerencsés a NUTS3 szint alatti területi egységekben is elvégezni. Itt azonban nem tudunk egy egységesen, összehasonlítható módon rendelkezésre álló mutót elmezni, mint a korábbiakban bemutatott GDP adatok esetében. Ugyanakkor a kistérségi szint vizsgálata elengedhetetlen, mivel a kutatás során vizsgált lakossági mozgások terét ez a területi szint adja elsősorban. Összevethetỏ adatok híján az irodalomból ismert, más forrásokhoz kell folyamodnunk. Két olyan vizsgálat adatai alapján mutatjuk be a területi fejlettséget, amelyek hasonló változói kör alapján becsülték a kistérségi szintű fejlettség különbségeit Szlovákiában és Magyarországon (4. ábra). Szlovákia esetében ehhez Kovács Ervin faktoranalízis alapján mutatja be a szlovák járások területi fejlettségi különbségeit (Kovács E. 2000), míg a magyar kistérség fejlettségét a KSH kistérségi fejlettségi besorolása alapján értlemezzük ( $K S H$ 2004). A két munka hasonlóképpen gazdasági fejlettségi/fejlődési és infrastrukturális mutatók alapján tipizálja a térségeket öt-öt kategóriában, igaz némi időbeli eltéréssel, de feltételezzük, hogy a térségek közötti különbségek ez alatt jelentősen nem változtak.

Mindezek alapján látható, hogy a két határtérségben hatványozottan érvényesek azok a területi különbségek, amelyeket a NUTS3 egységek bemutatásánál ábrázoltunk. A nyugati szakaszon, magyar oldalon az adott megyék fejlettebb térségei helyezkednek el a határ mentén. Ezt láthatjuk mindhárom megye esetében. GyörMoson-Sopron megyében a megyeszékhely kistérsége, míg Komárom-Esztergom megyében a Duna menti gazdasági fejlődési tengely hatására a határ menti kistérségek (a Dorogi kistérség kivételével) dinamikusan fejlödö területnek számítanak. Tehát a Duna, illetve a határ mentén egy egységesen fejlett, ipari, urbánus övezet alakult ki, amely Magyarország legfejlettebb vidéki megyéinek gazdasági húzótérségét is jelenti egyben. Szlovákiában a Duna mente kiemelkedő fejlettsége Pozsonyra és annak agglomerációjára korlátozódik. Nagyszombat kerület esetében a határ menti Dunaszerdahelyi járás a Nagyszombatihoz képest kevésbé fejlett, ám 
Tér és Társadalom, 22. 2008. 3. 3-25. p.

napjainkban dinamikusan fejlődő képet mutat. Mindenesetre fejlödését elsősorban Pozsony és Nagyszombat közelsége generálja. Általában szlovák oldalon a dinamikus, növekvő területek a Dunától északabbra helyezkednek el: Nagyszombat, Nyitra magasságában, miközben a határ menti térségek (különösen Komáromtól keletre) a háttértelepülések kategóriájába sorolhatók. Mindebból kiemelkedik természetesen Komárom, melynek közelkedés-földrajzi helyzete miatt is jelentős a helyzeti energiája. Fejlódése azonban szigetszerü.

\section{4. ÁBRA}

Fejlettségi különbségek NUTS4 szinten ${ }^{5}$

(Differencies of Development on NUTS4 Level)

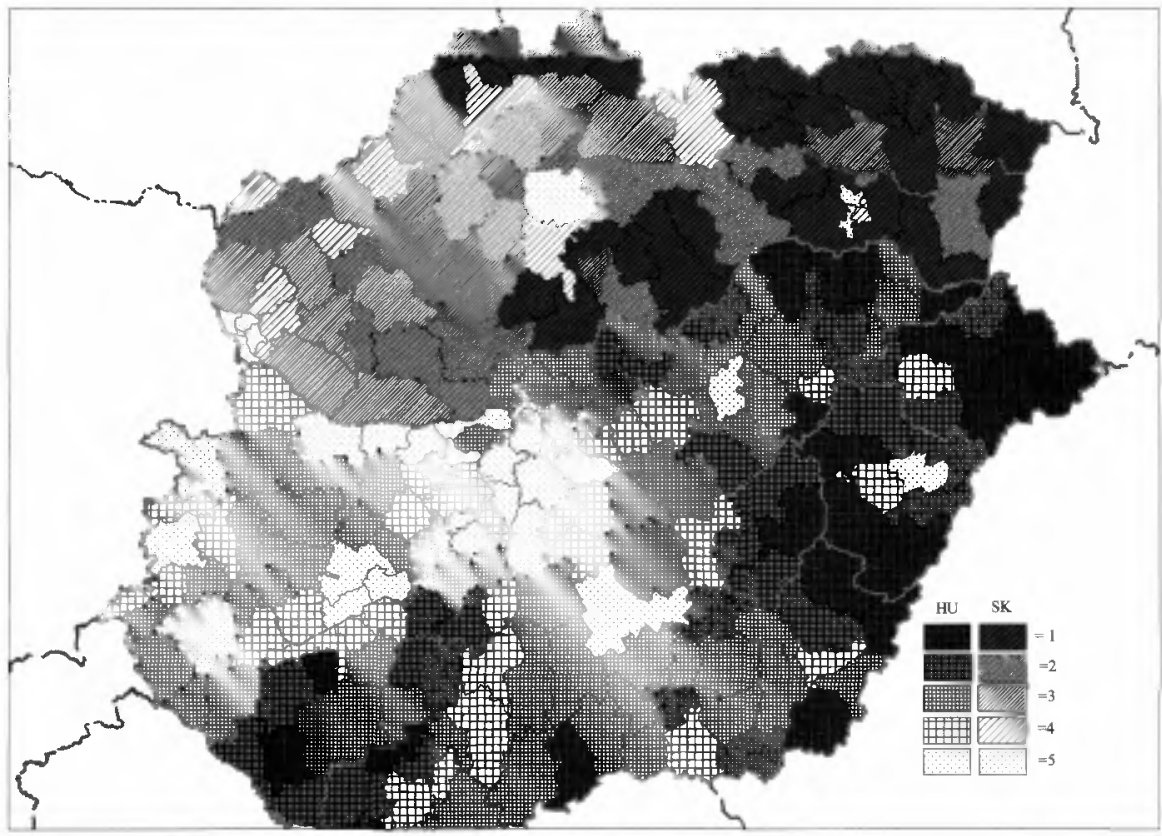

Jelmagyarázat: Magyarország: 1=lemaradó; 2=stagnáló; 3=felzárkózó; 4=fejlődő; 5=dinamikusan fejlödő kistérségek, KSH (2004) alapján.

Szlovákia 1=leghátrányosabb helyzetü; 5=legjobb helyzetủ járások, Kovács E. (2000) faktoranalízis számítása alapján.

Forrás: KSH (2004) és Kovács E. (2000, 243) alapján saját szerkesztés.

A keleti határszakaszon a helyzetkép szinte szimmetrikusnak mondható. A határ menti megyék/kerületek rosszabb helyzetủ térségeit találjuk a határ mentén. Érdekes jelenség, hogy kialakulnak viszonylag fejlettebb térség-párok. Ez alatt gondolhatunk Losonc és Salgótarján, valamint Rozsnyó és Kazincbarcika térségeire. Kiemelkedik Kassa fejlettsége, de mint a kerületi szintü elemzésnél utaltunk rá, s itt szemléletesen látszik is, térségi fejlesztő ereje kisebb, mint a nyugati, országos központé. A város fejlettsége mellett a legrosszabb helyzetú térségeket találjuk a központ körül, igy a határ mentén is. A legrosszabb helyzetü térségeket a legkeletibb szakaszon találjuk, a határ mindkét oldalán. 


\section{Városhálózat, vonzáskörzetek}

A Kárpát-medence határai fiatal történelmi képződmények, sokhelyütt nem szüntek meg, legfeljebb visszafejlödtek azok a mai határokat átszelő térszerkezeti struktúrák (közlekedési tengelyek, városi vonzáskörzetek), amelyek a határok elválasztó szerepének gyengülésével részben újraformálódhatnak. Ugyanakkor tudomásul kell vennünk, hogy az elmúlt évtizedekben Magyarországon és a szomszédos országokban is olyan térformáló folyamatok zajlottak le (indusztrializáció, urbanizáció, a közigazgatási struktúra és az etnikai viszonyok átalakulása), amelyek miatt sok esetben már nem állíthatók automatikusan vissza azok a területi kapcsolatok, amelyek a határok megvonása elött léteztek (5. ábra). Ugyanakkor keletkeztek új, korábban nem létezö, a mai határokon átívelő területi szükségszerüségek (szuburbanizáció, munkavállalói ingázás).

\section{5. ÁBRA}

Az államhatár által szétvágott városi vonzáskörzetek (Urban Catchments Areas in Border Regions Cut by Borders of Hungary)

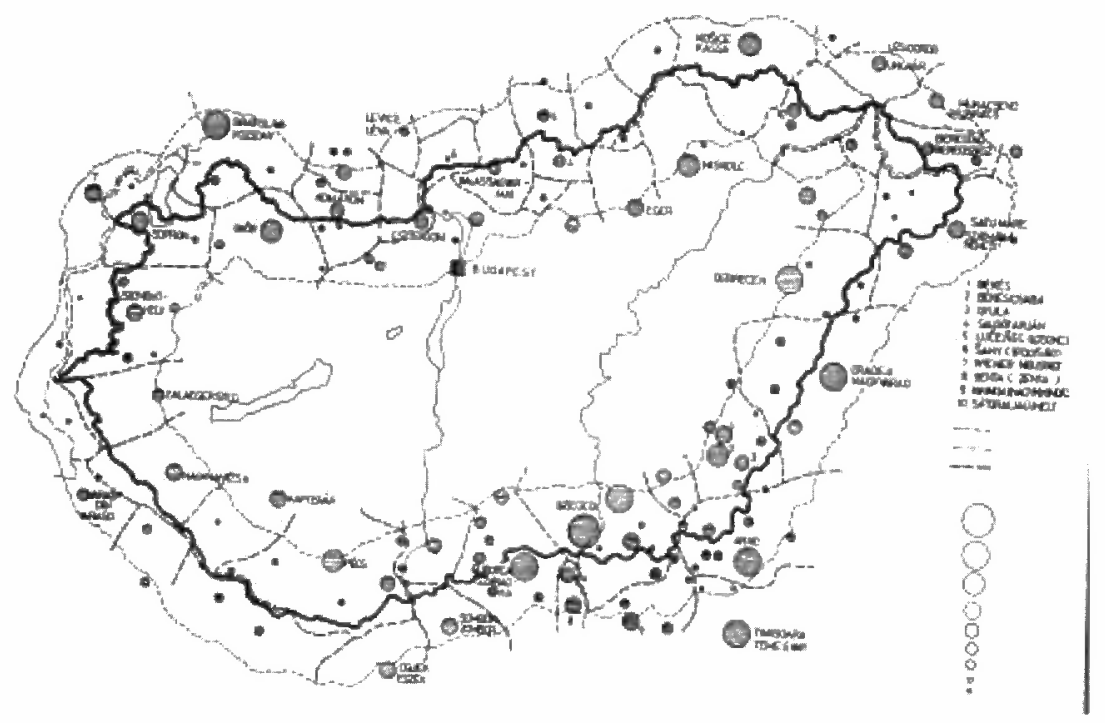

Forrás: Kovács Z. (1990).

A határok megvonása elött több olyan város is létezett, amely az új államterületeken elvesztette központi funkcióját, népessége alig növekedett, központi szerepköre lehanyatlott (pl. Balassagyarmat, Királyhelmec). E városok megyei, járási szerepüket elvesztve alacsonyabb hierarchikus kategóriába kerültek. Eleve a mai határ menti terüleken, különösen a hegyvidéki területeken kisebb volt városaink átlagos nagysága, mint az Alföldön, így nyilván azonos hierarchia szinthez is kisebb települések tartoztak (Beluszky-Györi 2005). Ezek a kisvárosok, közigazgatási szerepüket elvesztve gyakorlatilag megfosztódtak a 20. századi jelentős urbánus fejlődés lehe- 
tőségétől. Ugyanakkor több város létejött vagy megerősödött, a hierarchiában emelkedett az elmúlt évtizedek során, így szolgáltatásai már a határ másik oldalára is jelentősebb erővel fejtenek ki vonzerőt, mint történelme során. Ide tartozik maga Pozsony, de Dél-Komárom (Sikos T.- Tiner 2007) és Salgótarján is.

A nyugati részen közvetlenül a határ mentén nagyobb városokat találunk (Pozsony, Mosonmagyaróvár, Győr, a két Komárom, Esztergom-Párkány várospárok) (6. ábra), míg a keleti szakaszon a nagyobb városok a határtól távolabb helyezkednek el. Még a térségi központi funciók viszonylag teljességét nyújtó 20-50 ezer lakosú városok vonzásterei sem fedik le a teljes térséget. A hosszú határszakaszon a határ közelében Salgótarján, Ózd és Kazincbarcika, míg Szlovákiában Losonc és Rimaszombat található. Lényegében mindegyik kisváros, nagyságrendjét tekintve Salgótarján, a megyeszékhely is. Nagyobb központok (Kassa és Miskolc) a határtól kissé távolabb helyezkednek el. Szlovákiában a városfejlödés inkább a határtól északabbra következett be az elmúlt évtizedekben (Kassa kivételével), míg a határ mentént a 20. század eleji közepes városok nagy része megrekedt a korabeli lakosságszám szintjén (Horváth 2004). Így napjainkra jelentős nagyságú, városhiányos területek alakultak ki, különösen a Borsod-Abaúj-Zemplén megye és a Kassai kerület érintkezési övezetében.

\section{6. ÁBRA}

A városok lakosságszám szerint

(Cities and Towns by Number of Inhabitants)

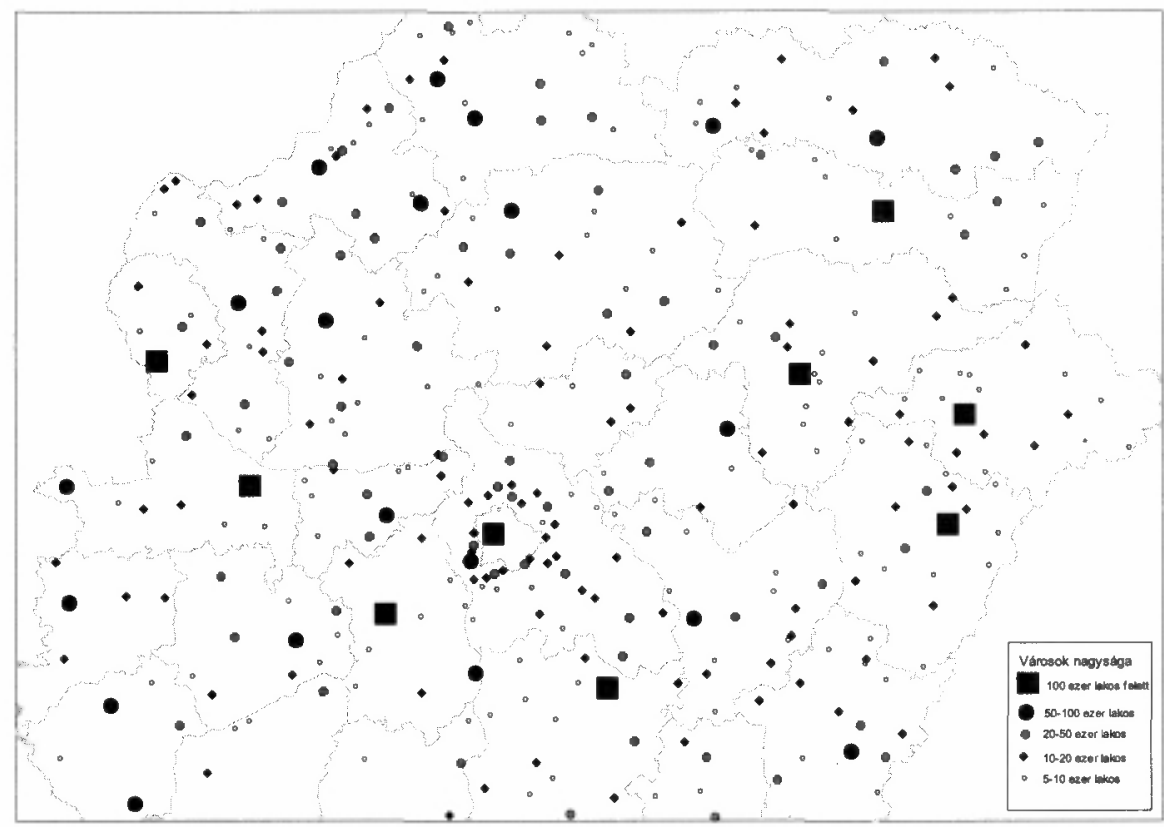

Forrás: Saját szerkesztés. 
A központok elhelyezkedése szerint a határtérséget öt tipikus, funkcionális övezetre lehet felbontani.

1) Pozsony agglomerációja. Ide értjük a szlovák oldali hagyományos szuburbán övezetet egészen Somorjáig, amely a legföbb ingázási övezete a szlovák fövárosnak. Agglomerációja ugyanakkor már túlnyúlt a határon, érinti Mosonmagyaróvár határhoz közeli térségét, valamint osztrák területeket is.

2) A dunai városok övezete. Ide érthetjük már Györt, valamint a dunai várospárokat, úm. Révkomárom/Komárom, Párkány/Esztergom. Különösen a két Komárom és Győr közlekedés-földrajzi helyzete predesztinálja jelentős határon átnyúló vonzáskörzet kialakulását. E városok különleges jelentőségét az adja, hogy lényegében egy urbánus tömörülésként kell ma már számolnunk velük. Így együttesen lakosságszámuk már meghaladja az ötvenezret, tehát egyesített közös szolgáltatásaik, gazdasági vonzerejük egy hazai közepes város potenciáljával egyezik meg, nem beszélve a Duna jobb partján elhelyezkedő gazdasági agglomeráció (Almásfüzítőtől Dorogig) népességtömörülésről.

3) A hegyvidék városok övezete. Az Ipoly torkolatától Kassa és Miskolc vonzáskörzetének határáig tart. Nyugati része még a Budapesti agglomerációt is érinti, ide számíthatjuk Vácot is. Ugyanakkor az Ipoly mente alacsony városodottságát Budapest elszívó hatásának is köszönheti. A Börzsöny és az Ipoly folyó közötti terület ugyanakkor Esztergom városhoz gravitál, amit a schengeni határok, s a tervezett Ipoly-hidak tesznek lehetővé. Az Északi-középhegységünk északi elöterében a már említett 20-50 ezer lakosú városok emelkednek ki (Salgótarján, Ózd, Kazincbarcika, Losonc, Rimaszombat), de a határtól kisebb-nagyobb távolságra $(10-20 \mathrm{~km})$. A határon közvetlenül csak kisebb központok találhatók (Ipolyság, Balassagyarmat).

4) Kassa és Miskolc vonzáskörzete. A két nagyváros határ menti térségére jellemzó, hogy különösen magyar oldalon az ország egyik leginkább városhiányos területe. Edelénytől északra, Zemplénben nem találunk jelentősebb központi települést. A határ mente inkább Kassa vonzáskörzetéhez tartozik, mint Miskolcéhoz.

5) A keleti hármashatár vidék. Ez a térség mindkét oldalon városhiányos. Kisebb központok csak a magyar oldalon találhatók, úm. Sátoraljaújhely, Sárospatak. Különösen az előbbi erős határon átnyúló vonzóhatással rendelkezik. Szlovák oldalon Tóketerebes a határtól kissé távol is fekszik, s szolgáltatásai viszonylag gyengék ahhoz, hogy a határ magyarországi oldalán is vonzóhatást fejtsen ki.

Bécs és Budapest hagyományos vonzáskörzeteit állítja helyre a kilencvenes évek közepétől fogva. Különösen Bécs lehetőségei kiemelkedőek e téren. Pozsonyt lényegében ,ikervárossá” tette, a gyorsabb, közös fejlődéshez elsősorban a közvetlen, jó minőségủ közlekedési összeköttetés hiányzik. Az osztrák vasúttársaság ingázó vonatai (eurorégió vonatok) ütemes menetrenddel, kedvezményes vasúti jegyekkel kötik a magyarországi (Tatabányáig, Szombathelyig), a szlovákiai és csehországi határ menti területeket az osztrák fövároshoz. Mindezek után nem csoda, ha a határtérség nyugati részében ismét a centrális, Bécs felé mutató kapcsolatok erősödnek. 
Tér és Társadalom, 22. 2008. 3. 3-25. p.

Budapest hasonló szerepet tölt, tölthet be Szlovákia középső részében. Ehhez viszont hiányoznak az infrastrukturális feltételek, amelyek kiépítése, megszervezése politikai nehézségekbe is ütközik. El lehet vajon képzelni azt a helyzetet, hogy autópálya, gyorsforgalmi út kötné össze a magyar fỏvárost Közép-Szlovákiával? Milyen problémák akadályozhatják, hogy a Vác, Szob felé irányuló ütemes, elővárosi vasúti közlekedés meghosszabbítható legyen Párkányig, Érsekújvárig? A két nagy fövároshoz képest Pozsony határon átnyúló szerepe csekély. Erősíti kapcsolatait Béccsel, jelentősek az osztrák befektetések, ma már gyorshajó köti össze naponta több járattal a két várost (Wienslava-Bratiswien), már megépült az autópálya, $\mathrm{s}$ valószínüsíthető a gyorsvasúti, ső́t nagysebességú vasúti összeköttetés kiépítése is. A szlovák föváros határon átnyúló vonzereje elsősorban a szuburbanizációján alapul. A gyorsan növekvő pozsonyi ingatlanárak éles ellentétben állnak a határ másik oldalán elhelyezkedő, saját országukban periférikusnak számító osztrák és magyar területek viszonylag alacsony ingatlanáraival. Így gyorsan megindult a pozsonyi népesség kiköltözése ezekre a területekre, s ingáznak a határon át a szlovák fövárosba. Ez a folyamat az utóbbi évben egyre erősebben érinti a magyarországi határ menti területeket, hiszen rendkívül jó közlekedési helyzetben vannak. A kiáramlást tovább erősíti a határellenőrzés megszúnése, ugyanakkor fékezi, hogy a magyar terület - ellentétben az osztrákkal - nem rendelkezik Pozsony irányába elővárosi tömegközlekedéssel. Az infrastruktúra rendelkezésre áll (autópálya, vasút). A közlekedés megszervezése esetén Pozsony agglomerációja Mosonmagyaróvárig nyúlna, hiszen egy szubrbanizálódó nagyvárosból nem csak a lakosság, hanem őket követve a gazdasági szereplök is kitelepülnek, keresve az alacsonyabb költségú telephelyi (iroda-bérleti) lehetőségeket, ahogyan az a budapesti és a bécsi agglomerációban is történt. Mindehhez kitüntetett jelentöségü, legértékesebb földrajzi pont egy nagyváros közelében elhelyezkedỏ autópálya kereszteződés térsége (lásd M1, M15).

A határ teljes hosszában megtalálhatók a kis- és közepes városok Györtől Kassáig, Sátoraljaújhelyig, amelyek a határ mindkét oldalára kiterjesztik vonzáskörzetüket valamilyen formában (Hardi-Pap 2006). Van, ahol ez az ingázó munkavállalásra, van ahol a közszolgáltatásokra, kereskedelemre, van, ahol az élet szinte teljes egészére kiterjed. Különösen a keleti szakaszon jellemzö, hogy a határ menti területek periférikus helyzetéért nagymértékben felelös a városi vonzáskörzetek szétvágása. Jelentős területek maradtak ellátatlanul a 20. század során, mivel a kis- és közepes városoktól a határ elvágta a falusi térségeket, $\mathrm{s}$ a helyettesítỏ központok távol voltak, rossz közlekedési körülmények között. A határ megvonása miatt több város elvesztette megyeszékhely rangját, $\mathrm{s}$ több város (fóleg keleten) a vonzáskörzet elvesztése miatt meg is állt fejlődésében (Mezei 2006).

Persze voltak olyan városok is, amelyek politikai és gazdasági hatásra fejlődtek. A szocializmus időszakában a politikai döntések mellett az ipari fejlődéshez kötött városi fejlődést preferáló gazdaságpolitikai döntések sok esetben hozták helyzetbe a határ menti térségeket. Magyarországon az északkelet-délnyugati irányú „,ipari tengely" fejlesztése, a szomszédos országokban a városi terek arányának növelése volt 
a cél. Ezzel párhuzamosan az iparfejlesztés határ menti városokat is érintett, mivel azok vagy hagyományos városi/ipari centrumok voltak, vagy földrajzi helyzetükből adódóan voltak fontosak. Így komoly ipari fejlödés bontakozott ki a magyarcsehszlovák határ dunai szakaszán (Pozsony, Győr, Komárom/Révkomárom, Érsekújvár, Lábatlan, Nyergesújfalu stb.), valamint keleti szakaszán (Salgótarján, Ózd, Putnok, Kazincbarcika, Kassa) is. Mindezekkel magyarázható, hogy az államszocializmus alatt a határtérségek nem minden esetben voltak azonosak a gazdasági perifériára szoruló térségekkel, számos határ menti terület és város jelentős fejlődési pályát futott be ez alatt az időszak alatt. Számos elemzés fel is hívja erre a figyelmet (Rechnitzer 1999; Süli-Zakar 2000; Baranyi 2004).

A városok elhelyezkedését vizsgálva ismét kiemelkedik a nyugati határszakasz kedvező helyzete. Itt közvetlenül a határon vagy a határ közelében helyezkednek el a közepes, nagyobb városok (Mosonmagyaróvár, Révkomárom, Esztergom stb.), amelyek közül Révkomárom és Esztergom kisebb méretü (20 ezer lakos alatti) várospárral (Komárom és Párkány) rendelkezik. Így egy átjárható határ esetén a szolgáltatások, beruházások szempontjából egy, jelentősebb urbánus térségnek számíthatnak. Maga a nyugati szakasz tehát urbanizáltnak tekinthető, a hármashatár térségben a magyar, a Dunán lejjebb pedig a szlovák oldal alacsonyabb városodottsági szintjét kompenzálják a másik oldal jelentősebb városi központjai. Tehát együttesen vizsgálva a két oldalt elmondhatjuk, hogy ez a szakasz városi központokkal jól ellátott térség, periférikus terület nem található benne.

Ezzel szemben az Ipoly torkolatától keletre rendre találunk városhiányos, periférikus térségeket. A határon, a határ közelében jelentősebb központként csak Salgótarjánt és Ózdot nevezhetjük meg, míg a kisebb városok közül Balassagyarmatot, Ipolyságot, Sátoraljaújhelyet. A többi város a határtól távolabb helyezkedik el (Losonc, Rimaszombat, Rozsnyó, Kazincbarcika). Távolságuk, méretük, gazdasági erejük folytán vonzáskőrzetüknek csak kis része tud a határon átnyúlni, segítvén a másik ország perifériáit. A nógrádi, abaúji szakaszokon a határtérségben nagy kiterjedésü, városhiányos területeket találhatunk, amelyeket akár külön, akár közösen vizsgálunk, periférikusnak tekinthetünk. A városok hiányához hozzájárul a domborzat, a hegyvidéki környezet, de a határ megvonásának ténye is, hiszen több magyarországi és szlovákiai város, vonzáskörzetét elveszítve a 20 . század során nem vagy csak csekély mértékben tudott növekedni. A 20. század második felének „szocialista városai” a rendszerváltással és a gazdasági struktúraváltással létalapjukat vesztették el, s szolgáltatásaik, általános fejlettségi színvonaluk máig kívánni valókat hagy maga után.

Keleten kiemelkedik Kassa szerepe. A regionális jelentőségü, fejlődő gazdaságú város vonzáskörzete Szlovákiában nagy, 60-100 kilométerre is kiterjed. Vonzáskörzetét könnyedén kiterjesztheti a hazai (zempléni, abaúji) térségekre. Mérete, potenciálja nagyobb, mint Miskolcé, azonban megkőzelíthetősége rosszabb. Valójában ez az a tipikus eset, amikor a két nagyváros együttmúködve egy szegény térségben jelentős gazdasági potenciált tudhatna magáénak. 
Tér és Társadalom, 22. 2008. 3. 3-25. p.

A településhálózat tehát alapvetően meghatározza a határon átnyúló régió formálódásának lehetőségét, az integráció mélységét. A nyugati szakasz városias, jó közlekedési adottságoknak örvendő térségei az elsó könnyítések hírére egymásra találtak, a határ közeli központok szervezik a közös határtérség életét. Keleten ezzel szemben a városi központok határon átnyúló szerepe elsősorban a másik oldal perifériảinak ellátása, a szolgáltatások elérhető távolságú biztositása lehet.

\section{Lakossági mozgások}

\section{A határtérségek lakosainak utazási aktivitása}

Lakossági kérdőíves kikérdezésủnk során vizsgáltuk a megkérdezettek határon átnyúló kapcsolatait, utazásait is. Ennek során több kérdésben is rákérdeztünk azokra a településekre, amelyeket rendszeresen vagy alkalom adtán felkeresnek a határ másik oldalán.

A határtérség lakosságának körében kicsi azon lakosok aránya, akik még nem keresték fel a másik oldalt. Összességében válaszadóink $88 \%$-a járt már a hatảr másik oldalán, ami mindenképpen hasonló arány a más határtérségekben megszokotthoz (Hardi 1999), pl az osztrák-magyar határtérségben, ahol a magyarok 10\%-a, míg az osztrákok 20\%-a nyilatkozott úgy, hogy még soha nem lépte át a határt. Jelen kutatásunk alapvető tapasztalata, hogy Szlovákiából többen keresik fel Magyarországot, mint fordítva. A Szlovákiában felvett kérdöívek válaszadói közül 96,1\% járt már Magyarországon, míg a magyarországi válaszadók esetében ez az arány csak 79,7\%. A szlovák-magyar határ esetében viszont meg kell különböztetnünk a magyarországi magyarokat és szlovákokat, valamint a szlovákiai magyarokat és szlovákokat, mivel a nemzetiségi hovatartozás befolyásolja az utazási szokásokat. Sajnos, kérdöívünk mintájába kevés magyarországi szlovák nemzetiségü lakos került, ők valamennyien jártak már Szlovákiában. A szlovákiai magyarok utazási intenzitása magas. Körükböl 97\%, míg a szlovákiai szlovák nemzetiségủ válaszadók 94\%-a járt már Magyarországon. A sort a magyarországi magyar nemzetiségủek zárják, akiknek 79,9\%-a lépte csak át a határt Szlovákia irányába. Tanulságos, hogy a legkevésbé a magyarországi lakosok vesznek részt a határon átnyúló mozgásokban. Ebben nyilvánvalóan szerepet játszik az a tény is, hogy a határ mentén élő szlovákok jelentős része tud vagy ért magyarul $(82 \%)$, tehát könnyebben intézi az ügyeit magyar oldalon, míg a magyarországi magyarok körében elenyésző a szlovákul tudók arány $(6,8 \%)$.

A határtérséget öt funkcionális szakaszra osztottuk fel: Pozsony agglomerációja, a dunai városok vonzástere, a hegyvidéki városok övezete, Kassa-Miskolc vonzáskörzete, keleti hármashatár vidék. Magyar oldalon találunk markáns különbségeket a válaszok között. A Pozsony agglomerációja szakaszon, amelyhez Magyarországon a Szigetköz nyugati részét, Mosonmagyaróvárt és vonzáskörzetét számítottuk, a legalacsonyabb az aktivitás. Innen válaszadónknak csupán 58\%-a kereste fel már Szlovákiát. Alacsony az arány Kassa-Miskolc vonzáskörzetében is $(74,8 \%)$. Itt nyilván szerepet játszik az, hogy a határ menti területek eleve rossz helyzetủek, igy 
a két legfontosabb átjárási cél, a munkavállalás és a vásárlás kevésbé motivál, ráadásul Miskolc révén a népesedés súlypontja már messze esik a határtól. Magyar oldalról a legmagasabb határátlépỏ arányokkal a keleti hármashatár övezetben, valamint a hegyvidéki kisebb városok övezetében találkozhatunk.

\section{Az utazások gyakorisága és motivációi}

Az utazások gyakorisága is elsősorban a szlovákiai oldal aktivitását mutatja. A szlovákiai válaszadók (akik valaha is jártak a határ másik oldalán) lényegesen gyakrabban utaznak Magyarországra, mint fordítva (2. táblázat). A naponta ingázók aránya is a szlovákiai válaszadók körében számottevő. Az Ipolytól nyugatra, nyilván elsósorban a munkavállalási lehetőségek miatt meghaladja a válaszadók 3\%-át.

\section{TÁBLÁZAT}

A határátlépók megoszlása az utazás gyakorisága szerint (\%)

(Breakdown of the Travellers by the Frequency of the Border-crossing)

\begin{tabular}{llccccc}
\hline Ország & $\begin{array}{c}\text { Határ- } \\
\text { szakasz }\end{array}$ & $\begin{array}{c}\text { Napi } \\
\text { rendsze- } \\
\text { rességgel }\end{array}$ & $\begin{array}{c}\text { Heti } \\
\text { rendsze- } \\
\text { rességgel }\end{array}$ & Havonta & $\begin{array}{c}\text { Évente } \\
\text { pár alka- } \\
\text { lommal }\end{array}$ & $\begin{array}{c}\text { Csak } \\
\text { néhány } \\
\text { évenént }\end{array}$ \\
\hline \multirow{2}{*}{ Magyaror- } & Nyugati* & 0,0 & 3,4 & 12,7 & 39,8 & 44,1 \\
& Keleti & 0,9 & 4,3 & 11,2 & 39,7 & 44,0 \\
& Összesen & 0,5 & 3,9 & 11,8 & 39,7 & 44,0 \\
\multirow{5}{*}{ Szlovákia } & Nyugati & 3,1 & 8,4 & 19,5 & 48,8 & 20,2 \\
& Keleti & 2,1 & 8,0 & 13,6 & 45,4 & 30,9 \\
& Összesen & 2,7 & 8,2 & 17,4 & 47,6 & 24,0 \\
\multirow{5}{*}{ Együtt } & Nyugati & 2,0 & 6,7 & 17,2 & 45,6 & 28,5 \\
& Keleti & 1,4 & 5,9 & 12,2 & 42,1 & 38,5 \\
& Összesen & 1,7 & 6,3 & 14,9 & 44,0 & 33,1 \\
\hline
\end{tabular}

* Szakaszok: az Ipolytól nyugatra, illetve keletre.

Forrás: Kérdőivek (2008) alapján.

Nem kevésbé fontos az utazások céljának meghatározása is. A 3. táblázat kérdőívünkben az utazás leggyakoribb okaként adott válaszok megoszlását mutatja be. A határátlépés okaként a munka és az üzleti ügyek kategória a határátlépők viszonylag kis arányánál szerepel, mint az utazást kiváltó ok. De ha ezt összevetjük azzal, hogy ez a cél erősen kapcsolódik a napi vagy heti rendszerességủ utazásokhoz, akkor láthatjuk, hogy súlyában egyre fontosabb ez a cél a határon átnyúló mozgások között. A tartós fogyasztási cikkek vásárlása a keleti hatrászakaszon jelentkezik erősebben, mind a két oldalon. Ezen a szakaszon a legjellemzőbb, hogy kölcsönösen a határ másik oldalán található a legközelebbi olyan városi központ, ahol a tartós fogyasztási cikkek nagyobb választékban állnak rendelkezésre. 
Tér és Társadalom, 22. 2008. 3. 3-25. p.

\section{TÁBLÁZAT}

A határátlépök megoszlása az utazás célja szerint (\%) (Share of the Cross-border Travellers by Purpose of the Trip)

\begin{tabular}{|c|c|c|c|c|c|c|}
\hline \multirow{2}{*}{$\begin{array}{r}\text { Határszakasz } \\
\text { Ország } \\
\text { Utazás oka }\end{array}$} & \multicolumn{2}{|c|}{ Nyugati* } & \multicolumn{2}{|c|}{ Keleti } & \multicolumn{2}{|c|}{ Összesen } \\
\hline & Magyar & Szlov. & Magyar & Szlov. & Magyar & Szlov. \\
\hline Munkavállalás & 1,3 & 4,1 & 0,4 & 3,3 & 0,8 & 3,8 \\
\hline Üzleti ügyek & 2,8 & 3,6 & 1,7 & 4,5 & 2,2 & 3,9 \\
\hline $\begin{array}{l}\text { Tartós fogyasztási } \\
\text { cikkek vásárlása }\end{array}$ & 6,6 & 18,7 & 21,7 & 22,8 & 15,6 & 20,1 \\
\hline $\begin{array}{l}\text { Heti, havi bevásár- } \\
\text { lás }\end{array}$ & 24,1 & 11,1 & 11,9 & 4,8 & 16,8 & 8,9 \\
\hline $\begin{array}{l}\text { Üdülés, pihenés, } \\
\text { városnézés }\end{array}$ & 44,9 & 35,2 & 39,7 & 46,8 & 41,8 & 39,3 \\
\hline $\begin{array}{l}\text { Kulturális rendez- } \\
\text { vények }\end{array}$ & 2,8 & 12,9 & 4,7 & 9,0 & 3,9 & 11,5 \\
\hline Rokonlátogatás & 5,4 & 10,5 & 10,0 & 5,1 & 8,1 & 8,6 \\
\hline Egyéb & 12,0 & 3,9 & 10,0 & 3,6 & 10,8 & 3,8 \\
\hline
\end{tabular}

* Szakaszok: az Ipolytól nyugatra, illetve keletre.

Forrás: Kérdöivek (2008) alapján.

A nyugati szakaszon hasonló a magyarázata annak, hogy a szlovák oldalról nagyobb arányban keresik fel a magyarországi városokat vásárlás céljával.

A heti, havi bevásárlás a magyarországi válaszadók körében ért el magasabb értéket. Hozzá kell tennünk, hogy ezek a mozgások azok, amelyek a leginkább konjunktúra érzékenyek. (Erről lásd Kovács András tanulmányát a Tér és Társadalom jelen számában).

Egyre fontosabbá válik a szabadidó eltöltés is, mint határtálépési cél. Az üdülés, pihenés hasonló súllyal szerepel mindkét oldal motivációi között. Igaz, mint látni fogjuk, az utazások nagy része nem a határtérséget, hanem attól távolabbi területeket érint. Ugyanakkor a városlátogatással, vásárlással összekötött pihenés, fürdő látogatás egyre gyakoribb mindkét oldal lakosai körében. A kulturális rendezvények látogatása elsősorban a szlovákiai magyarság részéröl utazási cél, míg a rokonlátogatás mindkét oldal esetében hasonló arányokat mutat.

Kiemelendő, hogy a vásárlásoknál nem tudtunk egységes, egyik országból a másikba mutató, fö irányokat bizonyítani. Ennek oka, hogy az árak ma többé-kevésbé kiegyenlítettek. Mára inkább jellemzően a központok elérhetősége válik az egyik legfontosabb szemponttá, s ezeken keresztül a kínálat bősége, a választék minősége. Így tehát a mozgásokat egyre inkább az országon belül is megszokott vonzáskörzeti irányok szablyák meg. 


\section{Céltelepülések}

Az utazások földrajzi céljára vonatkozóan több kérdést is feltettünk, így összességében mintegy négy és félezer település-említést tudtunk feldolgozni (7. ábra). Mindezek alapján látható, hogy az utazási célok mintegy $70 \%$-a található a vizsgálati határtérségünkben. Ezeken kívül mindkét ország nagy idegenforgalmi célterületei (Balaton, Magas-Tátra) emelkednek ki. Látható, hogy az országok távolabbi területei is érintettek, ezek elsösorban a rokonlátogatás révén kapcsolhatók be a vizsgálatainkba.

Magyarországon kiemelkedik Budapest, amelyet a szlovákiai válaszadók negyede jelölt be célként, változatos motivációkkal. Budapest után a térség két regionális központja: Kassa és Györ következik. A nyugati és keleti határszakasz két közponját a válaszadók 17 és 18\%-a jelölte úticélként. Komárom-Komarno különleges státuszát mutatja, hogy mindkét oldal céltelepülési listájában a harmadik helyen végzett. Mindent összevetve tehát itt tapasztalható a legintenzívebb lakossági mozgás (szlovák oldalról 14,5\%, míg magyar oldalról 8,8\% nevezte meg utazási célként). Komárom után Pozsony és Miskolc a két fontos cél. Pozsony a határtérség szempontjából periférián helyzekedik el, ezért a Magyarországról utazók kis része számára jelent célt. Miskolc hasonlóképpen kissé távol esik a határtól, így a napi tevékenységek szempontjából kevésbé vehetö számításba.

\section{7. ÁBRA}

Az utazások céltelepülései

(Destinations of the Cross-border Travels)

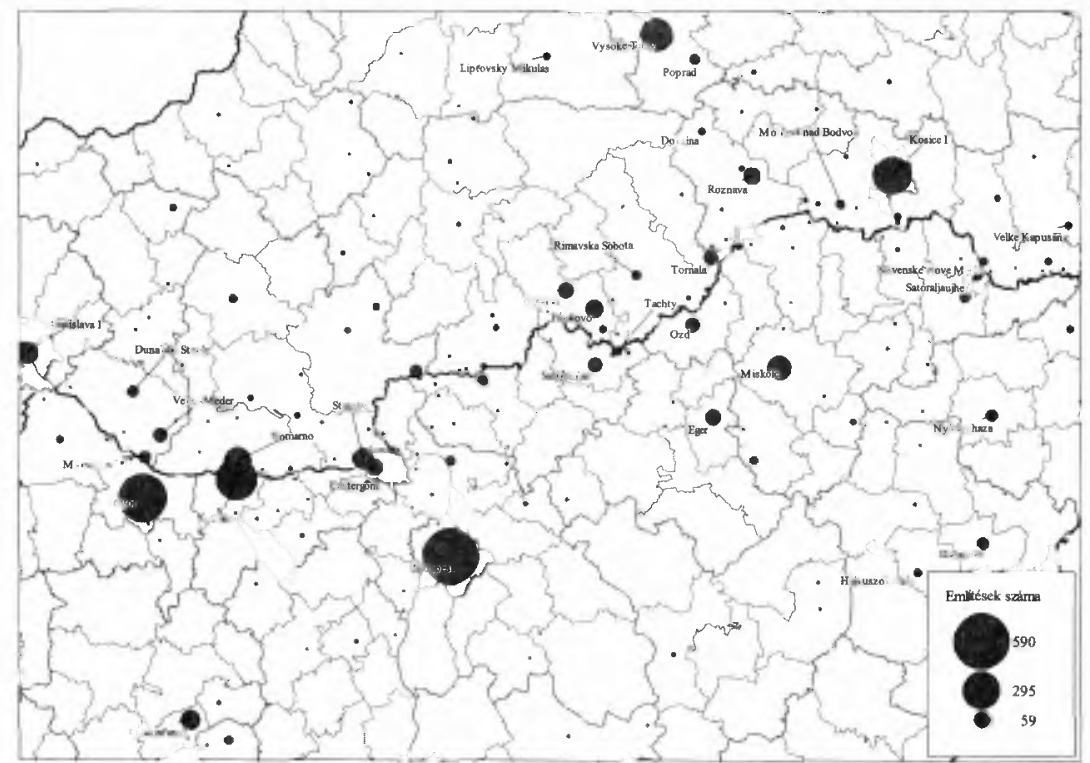

Forrás: Kérdöivek (2008) alapján. 
Összefoglalva elmondhatjuk, hogy a határ menti területek lakosai nagy arányban vesznek részt a határon átnyúló mozgásokban, igaz különbözö intenzitással. A mozgások legnagyobb része a határtérség területére esik, valamint elöszeretettel veszik igénybe a szomszédos ország ismert turisztikai célterületeit is. Látható, hogy fontos a térbeli közelség. Jelen tanulmányban hely hiányában nem tudjuk elemezni a válaszadók lakhelyei és a céltelepülések közötti összefüggést, az egy későbbi anyagban kerül bemutatásra.

\section{A térszerkezet sajátosságai}

A szlovák-magyar határ hosszúságánál, változatos természeti környezeténél fogva is - nem beszélve a társadalmi jellegzetességekröl - eltérö jellegü határtérségeket választ szét. Hagyományosan beszélhetünk a dunai (mintegy $180 \mathrm{~km}$ ) és a keleti (mintegy $499 \mathrm{~km}$ ) szakaszról. Ezt a felosztást természetesen tovább finomíthatjuk, hiszen a határ két oldalán eltérő fejlettségi szintủ területekkel találkozhatunk.

A dunai határszakasz kitủnik fejlettségével, s fejlődési lehetőségeivel. Magyarország összes határa közül talán itt van a legnagyobb esélyünk arra, hogy az ,integrált határrégió" megszülethessék. Központjai: Pozsony, Györ, Komárom, Esztergom fontos földrajzi tengelyek metszéspontjaiban helyezkednek el, hiszen észak-déli irányú, európai jelentóségủ szállítási útvonalak lépik át a Dunát, $\mathrm{s}$ találkoznak a nyugat-kelet (északnyugat-délkelet) irányú közlekedési tengelyekkel (ide sorolhatjuk magát a Dunát, valamint a Bécs-Budapest közúti és vasúti tengelyt. Mindezek a földrajzi tények felértékelik a térséget. A határrégióvá válást nagyban elősegíti, hogy a politikai határ mind a mai napig magyar többségủ etnikai területeket metsz, tehát a határ mentén helyezkednek el nagy kiterjedésủ és népességú, magyar többségú területek.

A térség történelmi megyehatárait vizsgálva megállapíthatjuk, hogy a Duna Pozsony és Győr között hagyományosan elválasztó szereppel bírt, hiszen a sok ágra szakadó folyó két partja között az átjárás csak Rajka és Győr magasságában valósulhatott meg. Moson, Pozsony és Györ megyék nem vagy csekély mértékben lépték át a folyót. A térség fö kommunikációs irányai Bécs felé mutattak, ami a természeti feltételek mellett a nagyváros vonzerejének is betudható. Győr felé azonban a Duna nem elválasztó, hanem térszervező vonalként vehetô számításba, hiszen a megyeközpontok (Komárom, Esztergom) a folyó partjára települtek, $\mathrm{s}$ a megyék is mindkét oldalra kiterjedöen alakultak ki.

Ha a gazdasági fejlettség mintázatát nézzük, együtt érdemes vizsgálni a szomszédos térségek országon belüli fejlettségi szintjét, gazdasági dinamizmusát, valamint a határ két oldalának különbségeit. (A vizsgálathoz a legegyszerübb, $\mathrm{s}$ többé-kevésbé egységesen beszerezhetö, valutaárfolyamon mért, egy före jutó bruttó hazai termék [GDP] összevetését végeztük el.) Mind a gazdasági fejlettségben, mind a dinamizmusban, a munkanélküliség mértékében szlovák oldalon kimutatható a nyugat-keleti lejtő, azzal a kiegészítéssel, hogy Kassa, mint Szlovákia decentruma a határ keleti végén ismét egy, Pozsonyhoz persze nem mérhetô növekedési központot alkot. 
A nyugati határszakaszon ugyanakkor a magyar és szlovák határtérség között jelentős fejlettségbeli különbséget tapasztalhatunk. Dél-Szlovákia gazdasága hagyományosan mezögazdaságra alapozódott, ipara, különösen a magyar oldallal összevetve gyenge, viszont dinamikusan fejlödő. Természetesen itt is meg kell különböztetnünk a pozsonyi agglomerációt, amely ma már Somorjáig terjed (Horváth 2004). Ezzel szemben a magyar oldal, különösen Györ és Esztergom között egy fejlett ipari térség, amely (részesedve természetesen a budapesti agglomeráció dinamizmusából is) a magyar központi térség után az ország talán leggyorsabban fejlódő területe. A határ keleti oldalán a fejlettségbeli különbségek lecsökkennek a két oldal között. A határ mindkét oldalán periférikus elhelyezkedésü, alacsony gazdasági fejlettségủ területek találhatók, magas munkanélküliséggel. Bár a megyei/kerületi szintủ adatok eltakarják, de Kassa térsége ebből némiképp kiemelkedik, a szlovák oldal javára billentve a megyei szint alatti, térségi fejlettségi mutatókat.

A szlovák-magyar határtérség lehet talán a leginkább alkalmas arra, hogy megvalósulhassék több, integrált határrégió, ahol a lakosság mozgását már nem a nemzetállami határok, hanem a térbeli logika szervezi. A nagyvárosok határon átnyúló tér-integráló ereje, a Duna menti sajátos várospárok, a szomszéd országban található kisvárosok hiánypótló funkciói biztosíthatják azt a többletet, amely a határ menti térségek életét javíthatja, $\mathrm{s}$ különlegessé teheti.

\section{Jegyzetek}

${ }^{1}$ Nemzeti Statisztikai Évkönyv (2005) alapján.

${ }^{2}$ A legtöbb országra az Eurostat adatait használtuk.

${ }^{3}$ Ukrajna (Kárpátalja), valamint Szerbia (a három, határ menti területi egység) esetében az értékeket becsültük, más adatforrások (nemzeti, tartományi statisztikai hivatalok) adatait felhasználva. Így a pontos értékekért nem vállalhatunk felelỏsséget, de összehasonlitás, viszonyítás céljára megfelelnek az adatok.

${ }^{4} \mathrm{Az}$ Eurostat adatai alapjản valutaárfolyamon számítva euróban.

${ }^{5} \mathrm{Az}$ ảbra alapjául szolgáló adatok a két ország esetében eltérỏ módszertannal készulltek, s némiképp eltérö időpontra vonatkoznak. Együttes bemutatása csupán a fejlettség országon belüli relativitásának összevetését szolgálja.

\section{Irodalom}

Baranyi B. (2004) A határmentiség dimenziói. Magyarország és keleti államhatárai. Dialóg Campus Kiadó, Budapest-Pécs.

Beluszky P. Gyổi R. (2005) Magyar városhálózat a 20. század elején. Dialóg Campus Kiadó, Budapest-Pécs.

Fleischer T. (2001) Régiók, határok, hálózatok. - Tér és Társadalom. 3-4, 55-67. o.

Gorzelak, G. (1995) Regional and Local Potential for Transformation in Poland. Regional and Local Studies 14. European Institute for Regional and Local Development, Warsaw.

Hansen, N. (1983) International Cooperation in Border Regions: an Overwiew and Research Agenda. International Regional Science Review. 8. 456-477. o.

Hardi T.-Mezei 1. (2003) Királyhelmectől Somorjáig: eurorégiók a szlovák-magyar határon.-FaluVáros-Régió. 8. 16-18. o.

Hardi T.-Pap N. (2006) Az államhatár megvonások hatása a Kárpát-medence és a Nyugat-Balkán városhálózatára - példák. - Pap N. (szerk.) A Balatontól az Adriáig. Lomart Kiadó, Pécs. 241-251. o. 
Hardi T. (1999) A határ és az enber. - Nárai M. Rechnitzer J. (szerk.) Elválaszt és összeköt - a határ. MTA RKK, Pécs-Györ. 159-189. o.

Hardi T. (2004) Az államhatáron átnyúló régiók formálódása. - Magyar Tudomány. 9. 991-1001. o.

Hevesi A.-Kocsis K. (2003) A magyar-szlovák határvidék földrajza. Lilium Aurum, Dunaszerdahely..

Horváth Gy. (szerk.) (2004) Dél-Szlovákia. Sorozatcím: A Kárpát-medence régiói 2. MTA RKK-Dialóg Campus Kiadó, Budapest-Pécs.

Kovács E. (2000) Regionális tagozódás Szlovákiában. - Tér és Társadalom. 2-3. 239-244. o.

Kovács Z. (1990) A határ menti területek központhálózatának átalakulása az elsỏ világháború utántól napjainkig. - Földrajzi Közlemények. 1-2.3-16. o.

KSH (2004) A kistérségek fejlettségi különbségei. - kartogramm. http://portal.ksh.hu/portal/ page? pageid $=37,411890 \& \_d a d=$ portal\&_schema $=$ PORTAL

Martinez, O.J. (1994) The Dynamics of Border Interaction: New Approaches to Border Analisys. - Schofield, C.H. (ed.) Global Boundaries (World Boundaries Series 1). Routledge, London-New York. 1-15. o.

Mezei I. (2006) Vonzáskörzetek és határok a magyar-szlovák határ mentén. - Lelkes G.-Tóth K. (szerk.) Nemzeti és etnikai kisebbségek Szlovákiában. Fórum Kisebbségkutató Intézet, Somorja. 107-196. o.

Novotny G. (2007) Határon átnyúló regionális hálózatok Európában. - Buday-Sántha A.- Lux G. (szerk.) Évkönyv 2006. PTE KTK Regionális Politika és Gazdaságtan Doktori Iskola, Pécs. 385-408. o.

Rechnitzer J. (1998) A területi stratégiák. Dialóg Campus, Budapest-Pécs.

Rechnitzer J. (1999) Határ menti együttmúködések Európában és Magyarországon. - Rechnitzer J.Nárai M. (szerk.) Elválaszt és összeköt a határ. MTA RKK, Pécs-Györ, 9-72. o.

Sikos T. T.-Tiner T. (2007) Egy város - két ország. Komárom-Komárno. Selye János Egyetem Kutatóintézete, Komárom.

Süli-Zakar, I. (2000) A Kárpátok Eurégió szerepe az átalakuló Közép-Európa határon átnyúló kapcsolataiban. - Abonyiné Palotás J.-Becsei J.-Kovács Cs. (szerk.) A magyar társadalomföldrajzi kutatás gondolatvilága. Szegedi Tudományegyetem Gazdaság- és Társadalomföldrajzi Tanszék, Szeged. 193-210. o.

\section{FEATURES OF THE BORDER REGION'S SPATIAL STURCTURE}

\section{TAMÁS HARDI}

This study analyses the spatial structure of Slovakian-Hungarian cross border region. The spatial structure, the city network and the transport axles influence largely the spatial coverage of cross border region. The Hungarian-Slovakian border is long and divides a various social-economic and natural surroundings. These areas belonged to one common state once; also it is interesting to study what kind of regional consequences a state border has got on regional development, city network and inhabitants' movement paths. At the end of the study the main target areas of respondents in other state's border region are represented as results of empirical research. 